\title{
The Impact of Green Brand Crises on Green Brand Trust: An Empirical Study
}

\author{
Gen $\mathrm{Li}^{*}$ and Xixiang Sun
}

School of Management, Wuhan University of Technology, Wuhan 430070, China; 13971190718@163.com

* Correspondence: mills0110@whut.edu.cn

check for updates

Citation: Li, G.; Sun, X. The Impact of Green Brand Crises on Green Brand Trust: An Empirical Study. Sustainability 2022, 14, 611. https:// doi.org/10.3390/su14020611

Academic Editors

Mingaleva Zhanna, Natalia Vukovic and Lazar Stošić

Received: 30 November 2021

Accepted: 3 January 2022

Published: 6 January 2022

Publisher's Note: MDPI stays neutral with regard to jurisdictional claims in published maps and institutional affiliations.

Copyright: () 2022 by the authors. Licensee MDPI, Basel, Switzerland. This article is an open access article distributed under the terms and conditions of the Creative Commons Attribution (CC BY) license (https:// creativecommons.org/licenses/by/ $4.0 /)$.

\begin{abstract}
In recent years, brand crises and greenwashing events have become common for Chinese consumers. However, compared to ordinary brands, it is more challenging for green brands to rebuild trust relationships with consumers after a green brand crisis due to their unique energy-saving and environmental protection attributes. The impact mechanism of green brand crises on consumer trust is complicated. To evaluate the different effects of different types of crises, this study used a sample of more than 1000 questionnaires to allow a regressive analysis, robustness test, endogenous test, mechanism test, and heterogeneity analysis. The study's results show that product functional and value-related crises harm green brand trust, and both brand perceived value and perceived risk play an intermediary role in the mechanism. Brand familiarity plays an essential role in the relationship between the green brand crisis and green brand trust.
\end{abstract}

Keywords: green brand; brand crisis; perceived risk; perceived value; trust relationship

\section{Introduction}

In response to climate change, China has determined goals and commitments to achieve carbon peaking and carbon neutralization, as well as to accelerate the promotion of green and low-carbon development in its latest socioeconomic development plans. However, the frequent occurrence of greenwashing [1] (a form of marketing spin in which green public relations and green marketing are deceptively used to persuade the public that an organisation's products, aims, and policies are environmentally friendly.) events cause an escalating number of green brand crisis events. This phenomenon eventually leads to the market downturn of green brands and an increasing crisis of consumers' trust in them [2]. Therefore, it is essential to determine the correct brand crisis strategy to repair the trust relationship after greenwashing [3]. An increasing number of studies have focused on trust relationship repair, including brand trust repair from the perspective of individuals [4] and organisations [4-6]. Scholars have also explored ways to repair trust relationships, including apologies [7], donations [8,9], denial [10], commitments [11], and excuses [12]. In addition, some scholars have investigated green brand trust restoration from the perspective of response time $[13,14]$. However, research on the mechanism of the impact of green brand crises on brand trust is still minimal [15].

Resolving the green brand trust crisis, eliminating consumers' doubts about buying green brands, and building a solid green brand consumer trust relationship are critical to rebuilding the public's confidence in green products and environmental protection $[15,16]$. Therefore, research on the mechanism of the impact of green brand crises on green brand trust has become a bottleneck [16]. While attempting to fill this gap, this study explores green brand crises in two ways. First, unlike previous studies on the impact of a single crisis, this study considers two types of crises, both of which can change the trust relationships between consumers and green brands: product function crises and value-related crises. Second, this study includes consumers' familiarity with the green brand as a regulatory variable. Consumers' understanding of the green brand is essential in determining whether 
consumers will continue to believe or give up after a brand crisis. The contribution of this study is that, on the one hand, studying the relationship between green brand crises and green brand trust can expand the existing theoretical framework of consumer brand relationships and provide a theoretical basis for revealing the internal mechanism of green brand crises and green brand trust. On the other hand, this study can help green brand managers to clarify the ways to prevent green brand crises and the direction of rebuilding green brand trust relationships after a green brand crisis.

\section{Literature Review and Hypothesis}

A green brand crisis and green brand trust are closely related to each other [13]. Both a green brand product functional crisis and a value-related crisis will reduce consumer trust [14]. When the products or services produced by a brand are defective and cannot reach their expected value, a product functional crisis will be formed [17]. If consumers of green brands cannot meet their green consumption needs when purchasing such products and the products do not meet green standards or have green functional defects, consumers' trust will be reduced [1]. Specifically, on the one hand, a product functional crisis will directly affect consumers' user experience, resulting in uncertainty and uncontrollability when consumers use the product [18]. On the other hand, a product functional crisis of a green brand represents intuitive crisis information for consumers. Consumers' perception of the crisis brought by intuitive information is easy to understand and feel [17], enabling consumers to quickly respond to the unmet needs of green consumption value.

When a brand violates moral standards or universal social values, a value-related crisis is formed [18]. This type of crisis will not affect the use of brand products but may affect the interests of others, thus affecting the social value expression of the brand [18]. Consumers buy green products to obtain additional social value from such products to improve their social identity [19]. However, when such green brands are being condemned by society, buying them will reduce one's social identity. When consumers perceive the threat that their social identity will be affected, they will avoid consuming relevant products and reduce their trust in the brand [19]. Moreover, compared to major brands, consumer loyalty is with vulnerable groups. When a brand has a value-related crisis, which affects the interests of other vulnerable groups, consumers will have empathy and reduce their trust in the brand [20].

More importantly, with the rapid development of internet technology, a brand crisis may be amplified and spread rapidly on networks, resulting in the centralised emergence of negative evaluations related to the brand in a short time [21] This large-scale and highly concentrated negative information will damage the construction of a brand image. When most consumers accept the setting that a brand will produce a crisis, consumers' confidence in the brand will gradually collapse [18]. This is fatal for a green brand because the brand needs a long time of operation and marketing to establish a green image. Once the green attribute of the brand is questioned, it may mean that consumers also question other functions of the brand.

In addition, it is worth noting that a product functional crisis will directly affect the vital interests of consumers. Consumers can instantaneously perceive the harm brought by a product functional crisis, while a value-related crisis often does not often directly affect consumers' use of products. Consumers' judgements and value identifications in value crises are different [19]. This makes it possible to trigger stronger negative emotions in consumers when a product functional crisis occurs.

Based on this, this paper puts forward the following assumptions:

Hypothesis (H1). A green brand crisis has a negative influence on green brand trust.

Hypothesis (H1a). A product functional crisis in a green brand has a negative influence on green brand trust. 
Hypothesis (H1b). A value-related crisis in a green brand has a negative influence on green brand trust.

When consumers buy products, they have expectations of these products. These expectations are not only judgments on whether their functions can be met, but are also affected by marketing means, brand reputation, after-sale service, and other factors [18]. Therefore, consumers' perceived value is a value judgement that includes consumers' subjective judgement [22]. When a brand crisis occurs, consumers will doubt the product function of the brand, doubt the value of the brand, or both [18]. Rational consumers will find that the consumption of the brand cannot meet the expected demand, thus reducing the overall evaluation of the value of the brand [23]. As a rational behaviour, the lower the perceived brand value is, the lower the consumer trust in the brand will be [24].

Owing to its green attributes, a green brand has the social value attributes of environmental protection and being green [25]. With the growing severity of environmental pollution, consumers' perceptions of pollution become stronger. The additional value recognition brought by green brands will be higher [25]. Therefore, consumers can favour green brands in the case of increasingly serious pollution problems, which improves the value perception of their products [26]. When consumers buy such green brand products, they are willing to pay additional costs to obtain environmental protection value recognition [19]. Therefore, under certain conditions, green brands can provide consumers with additional socially recognised values to enhance their perceived value and establish good consumer trust $[27,28]$. However, when a green brand has a brand crisis, consumers cannot get the corresponding value improvement despite the additional cost paid. In such cases, consumers feel that vast value gaps exist.

Specifically, when a green brand has a product functional value crisis, it means that the product does not realise the green function suggested by the brand publicity, such as energy saving [18]. In this situation, consumers pay extra costs for purchasing green products, but they do not get the corresponding return [13]. As a result, their recognition of the brand's green concept will be reduced and their perceived value will decrease [21]. More importantly, this will cause consumers to have further doubts about other functions of the brand's products, reduce the comprehensive value evaluation of the brand, reduce consumers' purchase intentions, and, finally, reduce consumers' trust [29].

When a value-related brand crisis occurs for green products, it means that the conceptual value of environmental protection provided by the brand cannot be reflected when purchasing its products [18]. Consumers cannot rely on purchasing such products to promote social value and social cognition and may even be isolated by surrounding people and have increased social costs. In this situation, the value brought by green brands may be negative, and the gap in consumers' perceived value will be expanded further. In this case, consumers will further question whether there is a crisis in other brand images they build, which might deepen the brand crisis and reduce their trust. In conclusion, the following assumptions are put forward:

Hypothesis (H2). A green brand crisis has a negative influence on consumers' perceived value of a green brand, thus significantly affecting green brand trust.

Hypothesis (H2a). A green brand product functional crisis has a negative influence on consumers' perceived value of a green brand, thus significantly affecting green brand trust.

Hypothesis (H2b). A green brand value-related crisis has a negative influence on consumers' perceived value of a green brand, thus significantly affecting green brand trust.

Perceived risk occurs when consumers cannot expect the results of the products they buy [30]. This risk perception includes consumers' uncertainty about the function of purchasing products and consumers' predictions of possible adverse consequences. It is a subjective feeling of a consumer. The greater the uncertainty and threat predicted 
are, the higher the perceived risk of consumers is. This perceived feeling of consumers will make them pursue advantages and avoid disadvantages. That is, it will reduce their trust in brands with high perceived risk, reduce their consumption of high-perceived-risk brand products, increase their trust in brands with low perceived risk, and increase their consumption of such products [31].

When studying the factors affecting perceived risk, the existing literature often divides the factors affecting it into time risk, functional risk, physical risk, financial risk, social risk, and psychological risk [32]. Different dimensions of factors affect the perceived risk of different industries differently and often do not exist alone [33]. The occurrence of a brand product functional crisis may include time, functional, physical, and financial risks. When a product functional crisis occurs in a green brand, consumers may repair or return relevant products. This increases the time risk. When the function of the product cannot meet the advertised use or the normal use is affected, the function risk increases. When the product has a security threat that may affect the safety of consumers' lives and property, the physical risk will increase. When the purchase of products leads to the loss of consumers' property, it will bring financial risk. The stacking of the above multi-dimensional factors will significantly enhance consumers' perceived risk of products. For green brands, an increase in perceived risk caused by functional risk may be the most severe [34]. Green brands will hype their energy-saving and green product functions to highlight their product characteristics in order to attract relevant customers [13]. Therefore, when consumers buy green brand products, they have expectations for their green functions [13]. When a product has functional risk, the expected green function cannot be realised. For expectant consumers, this is very sensitive. This emotional state will further encourage consumers to pursue advantages and avoid disadvantages. Consumers will quickly increase their perceived risk of a product and reduce their trust in a green brand because of an increase in the functional risk of the green brand [34].

Social risk and psychological risk are often more obvious when a brand has a valuerelated crisis. Social risk refers to the possibility that consumers may be excluded, ridiculed, and alienated by others when buying such products, thus directly affecting consumers social status [19]. Psychological risk refers to the risk that such products may have for consumers' values and their emotional state. For green brands, these two factors have a significant impact, as the performance of social responsibility that is attached to green products is an essential factor for consumers to be willing to buy such products [34]. Before purchasing green brand products, consumers will be affected by many marketing means, which will reduce their cognitive difficulties in the construction of green brand value, and they will think that such products will bring better social impact [35]. Consumers will consider buying such green products that will enhance their own social value and show their consumption attitudes and environmental awareness [35]. However, when the green brand has a value-related crisis, this type of crisis will reduce the brand value that it constructs and enhance consumers' doubts about this type of product [33]. When consumers buy such products, they are likely to affect their social status due to the reduction of their social evaluation and to be isolated by other consumers around them. Finally, a value-related brand crisis will enhance consumers' perceived risk and reduce their trust in green brands.

It should be noted that a product functional crisis in a green brand will increase consumer risks that are closely related to their survival, such as those of time, body, and finance. In contrast, a value-related crisis mainly increases consumers' social and psychological risks and will not affect consumers' survival. When consumers' survival is affected, their perceived risk in the products will increase significantly.

In conclusion, the following assumptions are put forward:

Hypothesis (H3). A green brand crisis has a positive influence on consumers' perceived risk of a green brand, thus significantly affecting green brand trust. 
Hypothesis (H3a). A green brand product functional crisis has a positive influence on consumers' perceived risk of a green brand, thus significantly affecting brand trust.

Hypothesis (H3b). A green brand value-related crisis has a positive influence on consumers' perceived risk of a green brand, thus significantly affecting green brand trust.

Brand familiarity refers to consumers' understanding of a brand's product. The higher consumers' familiarity with a brand is, the more consumers understand the product [36]. Essentially, brand familiarity means that consumers understand brand products, and it impacts consumers' consumption habits [37]. When consumers have a high degree of familiarity with a brand, they will actively process the information related to the brand and can quickly extract the relevant information in the case of similar consumer demand. The smooth and rapid extraction of this information will enhance consumers' willingness to buy the brand products and enhance consumers' trust in the brand [38]. Moreover, brand familiarity also means that consumers have more extensive associations with products. These associations are a critical factor for consumers in distinguishing the brand from other brand products [39]. When consumers have a very high familiarity with a brand, their memory will combine these associations with their consumption needs to affect their purchase decision making and emotional cognition of the brand, thereby enhancing brand trust [38].

When a brand crisis occurs, consumers who have a high degree of familiarity with a brand tend to interpret the attribution of the crisis in a more diversified manner than in an enterprise, which reduces the responsibility that consumers perceive in the enterprise, and thus reduces the impact of the brand crisis on brand trust [40]. When a brand has a product functional crisis, consumers with high brand familiarity are more willing to judge whether such a crisis will affect them through their own product consumption experience, rather than through the evaluations of others. If the above crisis does not occur in the products purchased, the brand crisis will not significantly impact consumers' perceived risk, and consumers will attribute the cause of the crisis to accidents. Although the social value of consumers with high brand familiarity will be affected when a brand has a value-related crisis, they need to conduct a new round of evaluation on the new brand if they want to change to another brand. For consumers, the cost of information collection is enormous. Moreover, as consumers are not familiar with new brands, after experiencing a brand value crisis, consumers will be more cautious about the choice of new brands. As such, the perceived risk of new brands will increase. Therefore, if consumers are familiar with a brand with a value-related crisis, to avoid generating more value costs, consumers should be more tolerant of the brand with the crisis, thus reducing the impact on the trust in the product of this brand [41].

When a brand crisis impacts consumers' perceived value and then affects brand trust, brand familiarity will also play a regulatory role. Specifically, brand familiarity will help consumers improve their fit with the brand and extend their brand value perception [41]. Therefore, when a brand crisis occurs, although it will affect consumers' expectations when purchasing the product, the brand's value perception for consumers with high brand familiarity is scattered in multiple dimensions, unlike for consumers with low brand familiarity. The perceived value of the brand depends on whether it can provide sufficient functions and reflect social value.

To summarise, the higher the brand familiarity is, the smaller the impact of the brand crisis on consumers' perceived value and the smaller the impact on brand trust caused by the brand crisis will be. In conclusion, the following assumptions are put forward:

Hypothesis (H4). The improvement of consumers' brand familiarity reduces the negative impact of a green brand crisis on green brand trust.

Hypothesis (H4a). The improvement of consumers' brand familiarity reduces the negative impact of a green brand product functional crisis on green brand trust. 
Hypothesis (H4b). The improvement of consumers' brand familiarity reduces the negative impact of a green brand value-related crisis on green brand trust.

Figure 1 illustrates the structural relationship between green brand crises, green brand trust, and the established hypotheses.

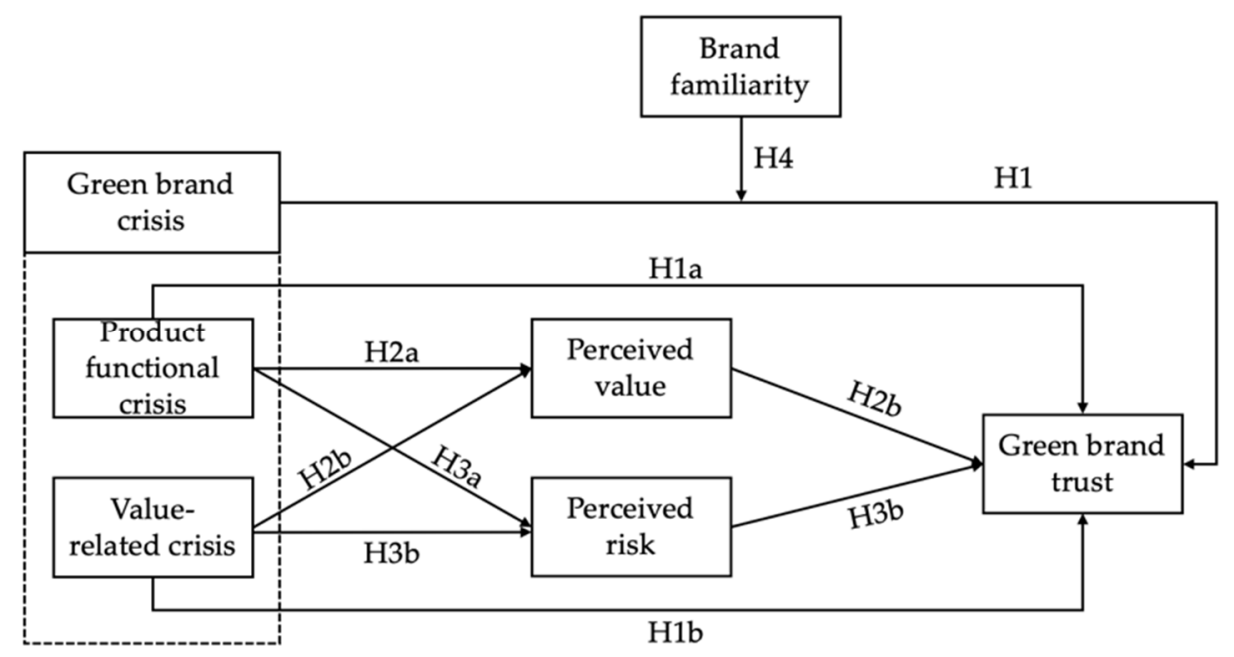

Figure 1. Structural relationship between green brand crises and green brand trust.

\section{Materials and Methods}

\subsection{Model Setting and Estimation Method}

This paper constructs the following model to identify the impact of a green brand crisis on green brand trust:

$$
\text { Brand_trust }_{i, j}=\alpha_{0}+\alpha_{1} \text { Brand_crisis }_{i, j}+\sum \alpha_{k} \text { Control }_{i, j}+\varepsilon_{i, j}
$$

In the above equation, Brand_trust $t_{i, j}$ indicates the green brand trust score of the $i$ th surveyed user for enterprise $j$. Brand_crisis ${ }_{i, j}$ indicates the green brand crisis score of the $i$ th surveyed user for enterprise $j$. Control ${ }_{i, j}$ is a series of control variables, including the gender, age, and educational background of the respondents. Consumers of different genders, ages, and education have different purposes for green brand consumption and pay varied attention to different green brands, which will affect their trust in the green brands and affect their views on green brand crises. Therefore, these personal characteristics need to be included in the control variables. Note that $\varepsilon_{i, j}$ is the residual term. Simultaneously, in order to reduce autocorrelation and heteroscedasticity, this paper controls the cluster-robust standard error at the individual level.

\subsection{Sample Selection and Data Sources}

The data were mainly derived from questionnaires. The questionnaires mainly collected consumers' opinions on a Lenovo mobile phone, Gree air conditioner, Midea air conditioner, TCL air conditioner, and Huawei mobile phone. These five enterprises are rated as green brands, and they are the top five brands with the highest incidence of crises. For each enterprise, the study distributed 200 questionnaires to investigate the response of consumer brand trust to green brand product functional crises and value-related crises (500 for each). A total of 1000 questionnaires were received, and 915 valid questionnaires were recovered. The effective questionnaire rate was $91.5 \%$. The questionnaires collected the respondents' characteristics, such as gender, age, and education, and investigated green brand crises, green brand trust, brand perceived value, brand perceived risk, and brand familiarity. The study designed multiple questions for each level to comprehensively evaluate consumers' evaluations of this level in different dimensions. 


\subsection{Variable Selection and Measurement Method}

1. Dependent variable. The dependent variable in this paper is green brand trust. The scale of green brand trust comes from Guo et al. [13]. This scale evaluates green brand trust from the four dimensions of if the brand is trustworthy, if the brand has a sense of responsibility, if it makes people feel safe and assured, and if it is not disappointing. It also sums up the scores of the four dimensions to obtain the impact of green brand trust. This paper refers to a method in the existing literature that assigns an equal difference value to the questionnaire answers. Specifically, it assigns a 1-5 point scale to strongly disagree, disagree, generally agree, comparatively agree, and strongly agree, respectively. Therefore, the higher the comprehensive score is, the higher the green brand trust will be.

2. Independent variable. This study provided consumers with a section on green brand crisis materials in relation to the function of products and a section on brand crisis materials about brand value so that the respondents could score the green brand crises based on different materials. Specifically, this paper performs its analysis by using six dimensions: causing serious harm to the enterprise, harming the enterprise's reputation, the impact on the brand being contrary to expectations, consumption bringing high risk, thinking that the severity of the crisis is very high, and causing severe negative impact. The scale of green brand crisis comes from Park et al. [42]. As with the dependent variable, five options were also set and assigned to a 1-5 point scale. Therefore, the higher the comprehensive score is, the more serious the green brand crisis that the consumers think/assume is.

3. Other variables. Firstly, this paper controls for a series of personal characteristics, including gender, age, and education. Secondly, the scale of perceived value comes from Cronin et al. [43]. The perceived value in this paper is obtained from a comprehensive evaluation of four dimensions: The value obtained is higher than the time and money paid, the product's value is higher than the expected value, the product can meet the demand, and the product value is very high. A higher the score means that consumers think that the perceived value of the green brand is higher. The scale of perceived risk comes from Cox et al. [44], who measured four dimensions: There is a risk in purchasing, it may lead to bad results, purchasing products will lead to uncertainty, and it will produce anxiety. The higher the comprehensive score is, the higher the consumer's perceived risk of the green brand is. The scale of brand familiarity comes from Kent et al. [45], who measured three dimensions: I can often see the advertisement of the green brand product or image, I can often see the display or sale of the green brand products, and I can often hear others talk about or recommend the green brand products. The higher the comprehensive score is, the higher the consumer's familiarity with the brand is. The scores for the perceived value, perceived risk, and brand familiarity are assigned similarly to those of the above variables. The description and statistics of each variable are shown in Table 1.

Table 1. Descriptive statistics.

\begin{tabular}{|c|c|c|c|c|c|c|}
\hline \multirow{2}{*}{ Variable Name } & \multirow{2}{*}{ Abbreviation } & \multirow{2}{*}{ Definition } & Mean Value & $\begin{array}{c}\text { Standard } \\
\text { Deviation }\end{array}$ & Mean Value & $\begin{array}{c}\text { Standard } \\
\text { Deviation }\end{array}$ \\
\hline & & & \multicolumn{2}{|c|}{ Product Functional Crisis } & \multicolumn{2}{|c|}{ Value-Related Crisis } \\
\hline Brand trust & brand_trust & Sum of four dimension question scores & 9.884 & 3.797 & 10.05 & 3.877 \\
\hline Brand crisis & brand_crisis & Sum of six dimension question scores & 21.45 & 4.897 & 21.39 & 4.901 \\
\hline Perceived value & value & Sum of four dimension question scores & 8.636 & 4.155 & 8.736 & 4.209 \\
\hline Perceived risk & dangerous & Sum of four dimension question scores & 15.44 & 3.913 & 15.43 & 3.802 \\
\hline Gender & gender & Male $=1$, Female $=2$ & 1.780 & 0.415 & 1.752 & 0.432 \\
\hline Age & age & $\begin{array}{c}\text { Under } 20=1,21-25 \text { years old }=2,26-30 \\
\text { years old }=3,31-35 \text { years old }=4, \text { Over } 35=5\end{array}$ & 2.810 & 0.862 & 2.806 & 0.900 \\
\hline Education & edu & $\begin{array}{c}\text { Below bachelor degree }=1, \text { Undergraduate }= \\
2, \text { Master degree or above }=3\end{array}$ & 1.990 & 0.756 & 2.010 & 0.742 \\
\hline
\end{tabular}

The results of the descriptive statistical analysis showed that female respondents accounted for about $75 \%$ of the sample, the mean value of the age was about 2.8 , indicating 
that most of the respondents were between 21 and 30 years old, and the mean value of the educational background was about 2 , indicating that most of the respondents had bachelor's degrees. The mean value of the brand crisis was about 21.4, indicating that the respondents believed that the five brand crisis cases in the questionnaire were very serious. The mean value of the perceived risk was about 15.4 , and the mean values of the perceived risk of the two types of green brand crises were almost the same, indicating that the respondents' degrees of perceived risk for the two types of green brand crises were almost the same. For the mean value of the perceived value, the green brand valuerelated crisis was rated higher than the product functional crisis, which indicated that when consumers faced green brand product functional crisis, it had a greater impact on their perceived value. Finally, for the mean value of green brand trust, the mean value for the green brand product functional crisis was lower than that of the green brand value-related crisis, which shows that when a green brand product functional crisis appears, it has a greater impact on consumers' green brand trust.

\section{Results and Discussions}

\subsection{Benchmark Regression Results and Analysis}

The estimation results of model (1) are shown in Table 2. Columns 1-2 represent the results of not adding individual characteristic control variables, such as gender, age, and education, and columns 3-4 represent the regression results when adding individual characteristic variables. Specifically, the results of the impact of product functional crises in green brands on green brand trust are shown in columns 1 and 3. After adding the individual feature control variable, brand_crisis negatively affects brand_trust at the 1\% level. The value of the coefficient is -0.452 , which shows that when consumers think that a product functional crisis of a green brand is greater, the green brand trust is lower. According to the results, Hypothesis H1a can be accepted. Thus, it can be concluded that a product functional crisis of a green brand has a negative impact on green brand trust.

Columns 2 and 4 in Table 2 provide the impact of brand value-related crises on green brand trust. After controlling for the personal characteristics, brand_crisis negatively affects brand_trust at the $1 \%$ level, and the value of the coefficient is -0.424 , indicating that green brand trust is reduced when the enterprise has a green brand value-related crisis. According to the results, Hypotheses $\mathrm{H} 1$ and $\mathrm{H} 1 \mathrm{~b}$ can be accepted.

Table 2. Benchmark regression results.

\begin{tabular}{|c|c|c|c|c|}
\hline & $\begin{array}{l}\text { (1) } \\
\text { Product Functional Crisis } \\
\text { brand_trust }\end{array}$ & $\begin{array}{c}(2) \\
\text { Value-Related Crisis } \\
\text { brand_trust }\end{array}$ & $\begin{array}{l}(3) \\
\text { Product Functional Crisis } \\
\text { brand_trust }\end{array}$ & $\begin{array}{c}(4) \\
\text { Value-Related Crisis } \\
\text { brand_trust }\end{array}$ \\
\hline brand_crisis & $\begin{array}{c}-0.454^{* * *} \\
(0.030)\end{array}$ & $\begin{array}{c}-0.425^{* * *} \\
(0.036)\end{array}$ & $\begin{array}{c}-0.452 * * * \\
(0.030)\end{array}$ & $\begin{array}{c}-0.424^{* * *} \\
(0.036)\end{array}$ \\
\hline gender & & & $\begin{array}{c}0.298 \\
(0.345)\end{array}$ & $\begin{array}{c}0.279 \\
(0.319)\end{array}$ \\
\hline age & & & $\begin{array}{c}0.125 \\
(0.169)\end{array}$ & $\begin{array}{c}0.020 \\
(0.167)\end{array}$ \\
\hline edu & & & $\begin{array}{l}-0.127 \\
(0.185)\end{array}$ & $\begin{array}{l}-0.242 \\
(0.187)\end{array}$ \\
\hline Constant term & $\begin{array}{c}19.620^{* * *} \\
(0.696)\end{array}$ & $\begin{array}{c}19.139 * * * \\
(0.834)\end{array}$ & $\begin{array}{c}18.954^{* * *} \\
(1.173)\end{array}$ & $\begin{array}{c}19.064^{* * *} \\
(1.210)\end{array}$ \\
\hline F & 224.227 & 135.546 & 56.076 & 34.765 \\
\hline $\mathrm{R}^{2}$ & 0.343 & 0.288 & 0.345 & 0.292 \\
\hline $\mathrm{N}$ & 500 & 500 & 500 & 500 \\
\hline
\end{tabular}

Note: ${ }^{* * *}$ is significant at the $1 \%$ level. Robust standard error is in brackets. 


\subsection{Robustness Check}

Although in the benchmark test part, this paper avoided the problem of possible missing variables by controlling for a series of personal characteristics and using the cluster-robust standard error at the individual level to control autocorrelation and heteroscedasticity, the results may still be disturbed by other factors, resulting in a bias in the regression results. Therefore, in the robustness test, this paper replaced the cluster-robust standard error and used the fixed effect to test the robustness of the regression results.

\subsubsection{Replacing the Cluster-Robust Standard Error}

In the benchmark regression, this paper used the cluster-robust standard error at the individual level. However, replacing the cluster-robust standard error at the enterprise level could test whether the use of the individual-level standard error would produce deviation, which would have a direct impact on the significance of the benchmark regression. Therefore, the replacement of the cluster-robust standard error is shown in columns 1-2 of Table 3. The results in column 1 of Table 3 show that after using the cluster-robust standard error at the enterprise level, the impact of the green brand product functional crisis on the green brand trust was still negative and significant at the $1 \%$ level. Although the value of the standard error increased, the impact coefficient and significance level did not change, indicating that the negative impact of the green brand product functional crisis on green brand trust still exists. The results of the benchmark regression are relatively robust.

Table 3. Robustness check.

\begin{tabular}{|c|c|c|c|c|}
\hline & (1) & (2) & (3) & (4) \\
\hline & \multicolumn{2}{|c|}{ Replaced Cluster-Robust Standard Error } & \multicolumn{2}{|c|}{ Fixed Effect } \\
\hline & brand_trust & brand_trust & brand_trust & brand_trust \\
\hline \multirow[t]{2}{*}{ brand_crisis } & $-0.452 * * *$ & $-0.424^{* * *}$ & $-0.454^{* * *}$ & $-0.419 * * *$ \\
\hline & $(0.047)$ & $(0.013)$ & $(0.030)$ & $(0.036)$ \\
\hline \multirow[t]{2}{*}{ gender } & 0.298 & 0.279 & 0.288 & 0.242 \\
\hline & $(0.207)$ & $(0.399)$ & $(0.349)$ & $(0.318)$ \\
\hline \multirow[t]{2}{*}{ age } & 0.125 & 0.020 & 0.141 & 0.056 \\
\hline & $(0.119)$ & $(0.166)$ & $(0.168)$ & $(0.161)$ \\
\hline \multirow[t]{2}{*}{ edu } & -0.127 & -0.242 & -0.102 & 0.106 \\
\hline & $(0.152)$ & $(0.124)$ & $(0.199)$ & $(0.201)$ \\
\hline Fixed effect & no & no & yes & yes \\
\hline \multirow{2}{*}{ Constant term } & $18.954^{* * *}$ & $19.064^{* * *}$ & $18.737^{* * *}$ & $19.053^{* * *}$ \\
\hline & $(1.187)$ & $(0.555)$ & $(1.202)$ & $(1.228)$ \\
\hline$R^{2}$ & 0.345 & 0.292 & 0.350 & 0.313 \\
\hline $\mathrm{N}$ & 500 & 500 & 500 & 500 \\
\hline
\end{tabular}

Note: ${ }^{* * *}$ is significant at the $1 \%$ level. Robust standard error is in brackets.

The results in column 2 of Table 3 show that after replacing the cluster-robust standard error at the enterprise level, the impact of the value-related green brand crisis on green brand trust was still negative and significant at the $1 \%$ level. Except for the standard error, which changed to some extent, the significance level and impact coefficient did not change. This shows that a value-related green brand crisis will still reduce the impact of consumers on green brand trust, and the result of the benchmark regression is relatively stable.

\subsubsection{Joining the Fixed Effect at the Enterprise Level}

To control the impact of enterprise-level non-change overtime on brand trust, this paper further adds the enterprise-level fixed effect to model (1). The results are shown in columns 3-4 of Table 3. The third column is the impact of the product functional brand crisis on brand trust after controlling the enterprise fixed effect. The results show that brand_crisis negatively affects brand_trust at the $1 \%$ level. The value of the coefficient of trust is -0.454 , which is consistent with the result of benchmark regression. The green 
brand crisis of product function will still negatively affect consumers' green brand trust, and the result of the benchmark regression is relatively stable.

The results in column 4 show that after adding the fixed effect at the enterprise level, brand_crisis still negatively affects brand_trust at the $1 \%$ level, and the value of the coefficient is -0.419 , indicating that the value-related green brand crisis will still reduce consumers' green brand trust, which shows that the result of the benchmark regression is relatively stable.

\subsection{Further Treatment of Endogenous Problems}

Although this paper adds individual characteristics to the model and alleviates the problems of missing variables by controlling fixed effects, many variables continue to be challenging to measure and control. This affects the relationship between green brand crises and green brand trust. More importantly, there may be a reverse causal relationship between green brand trust and green brand crises, that is, the higher consumers' trust in a green brand is, the higher their tolerance for a green brand crisis is, and the more they can accept the occurrence of a green brand crisis and reduce their judgement of such a crisis. Therefore, the endogenous problem in the research still needs to be solved. Based on the above situation, this paper alleviates the above problems by constructing tool variables.

Specifically, referring to the method of constructing instrumental variables by Lewbel [46], this paper takes the comprehensive score of consumers for the green brand crisis of an enterprise minus the average of the comprehensive crisis scores of all consumers of the enterprise, and then calculates the third power of the difference as an instrumental variable of green brand crisis, namely, $\left[\text { Brand }_{\text {crisisi }, j}-E\left(\text { Brand }_{-} \text {crisis } j\right)\right]^{3}$. The estimation results of the two-stage least squares method are shown in Table 4. Among them, columns 1-2 represent the impact of product functional green brand crises on green brand trust, and columns 3-4 represent the impact of value-related green brand crises on green brand trust.

Table 4. Tool variable results.

\begin{tabular}{|c|c|c|c|c|}
\hline & (1) & (2) & (3) & (4) \\
\hline & One Stage & Second Stage & One Stage & Second Stage \\
\hline & brand_crisis & brand_trust & brand_crisis & brand_trust \\
\hline brand_crisis & & $\begin{array}{c}-0.474^{* * *} \\
(0.0374)\end{array}$ & & $\begin{array}{c}-0.373 * * * \\
(0.0396)\end{array}$ \\
\hline iv_brand_crisis & $\begin{array}{l}0.00672 * * * \\
(0.000265)\end{array}$ & & $\begin{array}{l}0.00651^{* * *} \\
(0.000253)\end{array}$ & \\
\hline gender & $\begin{array}{c}0.142 \\
(0.353)\end{array}$ & $\begin{array}{c}0.288 \\
(0.334)\end{array}$ & $\begin{array}{c}0.214 \\
(0.334)\end{array}$ & $\begin{array}{c}0.284 \\
(0.340)\end{array}$ \\
\hline age & $\begin{array}{l}0.0737 \\
(0.169)\end{array}$ & $\begin{array}{c}0.123 \\
(0.160)\end{array}$ & $\begin{array}{l}-0.256 \\
(0.160)\end{array}$ & $\begin{array}{l}0.0389 \\
(0.164)\end{array}$ \\
\hline edu & $\begin{array}{c}0.378 * * \\
(0.192)\end{array}$ & $\begin{array}{l}-0.123 \\
(0.182)\end{array}$ & $\begin{array}{c}0.141 \\
(0.194)\end{array}$ & $\begin{array}{l}-0.245 \\
(0.198)\end{array}$ \\
\hline Constant term & $\begin{array}{c}20.75^{* * *} \\
(0.934)\end{array}$ & $\begin{array}{c}19.44^{* * *} \\
(1.210)\end{array}$ & $\begin{array}{c}22.01^{* * *} \\
(0.883)\end{array}$ & $\begin{array}{c}17.92^{* * *} \\
(1.265)\end{array}$ \\
\hline $\mathrm{R}^{2}$ & 0.566 & 0.344 & 0.574 & 0.288 \\
\hline $\mathrm{N}$ & 500 & 500 & 500 & 500 \\
\hline
\end{tabular}

The benchmark regression shows that the product functional green brand crisis has a negative impact on green brand trust, which is relatively stable. The results in column 2 show that the product functional green brand crisis still has an impact on green brand trust at a $1 \%$ level of significance and that the correlation is negative, indicating that the results of the instrumental variable regression are consistent with those of the benchmark regression. The results in column 4 show that the impact of the value-related green brand crisis on green brand trust is negative and significant at the $1 \%$ level, which is also consistent with the results of the benchmark regression, indicating that the conclusion assuming that a 
value-related crisis has a negative impact on brand trust is relatively stable. The impact of a green brand crisis on green brand trust does exist and is significant.

\subsection{Mechanism Test}

\subsubsection{Mediating Effect Test}

A previous paper found that a green brand crisis will harm consumers' green brand trust. Essentially, this impact may be generated through consumers' perceived risk and perceived value of the green brand, that is, on the one hand, the generation of a green brand crisis will enhance consumers' perception of the crisis in the green brand and reduce their trust in this green brand. On the other hand, the occurrence of a green brand crisis will reduce consumers' perceived value of the green brand, thus reducing their green brand trust. To test whether the above mechanism is established, this paper uses the stepwise method to test the intermediary effect. The specific model is constructed as follows:

$$
\begin{gathered}
\text { mediation }_{i, j}=\theta_{0}+\theta_{\text {med }} \text { Brand_crisis }_{i, j}+\sum_{i=1}^{k} \omega_{i} \operatorname{Con}_{i, j}+\varepsilon_{i, j} \\
\text { Brand }_{\text {trust } i, j}=\varphi_{0}+\varphi_{C R} \text { Brand_crisis }_{i, j}+\varphi_{\text {med }} \text { mediation }_{i, j}+\sum_{i=1}^{k} \omega_{i} \text { Con }_{i, j}+\varepsilon_{i, j}
\end{gathered}
$$

mediation $_{i, j}$ in Equations (2) and (3) are intermediary variables measured by the perceived value value $_{i, j}$ and perceived risk dangerous $s_{i, j}$, respectively. The first step of the step-by-step method is to test whether a green brand crisis will affect green brand trust based on the significance $\alpha_{1}$ in the test model (1), and then, in turn, to test the coefficient $\theta_{\text {med }}$ in Equation (2) and coefficient $\varphi_{\text {med }}$ in Equation (3). If both are significant, it means that an indirect effect exists, and the test in step 3 is carried out. If at least one is not significant, the test in step 2 is performed. Step 2 directly tests the original hypothesis $\theta_{\text {med }} \times \varphi_{\text {med }}=0$ with a bootstrap method; if it is significant, the mediating effect is significant. Step 3 is carried out; otherwise, the analysis is stopped. Step 3 tests the coefficient $\varphi_{C R}$ in Equation (3). If it is not significant, the direct effect is not significant, indicating that there is only an intermediary effect in the model. If it is significant, it indicates that there is an intermediary effect. The test results of the mediating effects are shown in Tables 5 and 6.

\begin{tabular}{|c|c|c|c|c|}
\hline & $\begin{array}{c}\text { (1) } \\
\text { dangerous }\end{array}$ & $\begin{array}{c}\text { (2) } \\
\text { brand_trust }\end{array}$ & $\begin{array}{c}\text { (3) } \\
\text { value }\end{array}$ & $\begin{array}{l}\text { (4) } \\
\text { brand_trust }\end{array}$ \\
\hline brand_crisis & $\begin{array}{c}0.345^{* * *} \\
(0.035)\end{array}$ & $\begin{array}{c}-0.364^{* * *} \\
(0.033)\end{array}$ & $\begin{array}{c}-0.352^{* * *} \\
(0.037)\end{array}$ & $\begin{array}{c}-0.367^{* * *} \\
(0.033)\end{array}$ \\
\hline value & & & & $\begin{array}{c}0.242^{* * *} \\
(0.042)\end{array}$ \\
\hline dangerous & & $\begin{array}{c}-0.254^{* * *} \\
(0.043)\end{array}$ & & \\
\hline gender & -0.110 & 0.270 & 0.231 & 0.242 \\
\hline & $(0.393)$ & $(0.325)$ & $(0.403)$ & $(0.331)$ \\
\hline age & -0.074 & 0.106 & -0.003 & 0.125 \\
\hline & $(0.179)$ & $(0.163)$ & $(0.197)$ & $(0.164)$ \\
\hline edu & 0.123 & -0.096 & -0.252 & -0.066 \\
\hline & $(0.213)$ & $(0.175)$ & $(0.213)$ & $(0.177)$ \\
\hline Constant term & $\begin{array}{c}8.196^{* * *} \\
(1.355)\end{array}$ & $\begin{array}{c}21.038^{* * *} \\
(1.132)\end{array}$ & $\begin{array}{c}16.278^{* * *} \\
(1.373)\end{array}$ & $\begin{array}{c}15.009 * * * \\
(1.328)\end{array}$ \\
\hline $\mathrm{F}$ & 25.287 & 68.030 & 23.947 & 65.770 \\
\hline $\mathrm{R}^{2}$ & 0.189 & 0.401 & 0.177 & 0.403 \\
\hline $\mathrm{N}$ & 500 & 500 & 500 & 500 \\
\hline
\end{tabular}

Table 5. Intermediary effect of product functional crises.

Note: ${ }^{* * *}$ is significant at the $1 \%$ level. Robust standard error is in brackets. 
Table 6. Intermediary effect of a value-related crisis.

\begin{tabular}{|c|c|c|c|c|}
\hline & $\begin{array}{c}\text { (1) } \\
\text { dangerous }\end{array}$ & $\begin{array}{c}\text { (2) } \\
\text { brand_trust }\end{array}$ & $\begin{array}{c}\text { (3) } \\
\text { value }\end{array}$ & $\begin{array}{c}\text { (4) } \\
\text { brand_trust }\end{array}$ \\
\hline brand_crisis & $\begin{array}{c}0.326^{* * *} \\
(0.038)\end{array}$ & $\begin{array}{c}-0.386^{* * *} \\
(0.039)\end{array}$ & $\begin{array}{c}-0.351^{* * *} \\
(0.039)\end{array}$ & $\begin{array}{c}-0.346^{* * *} \\
(0.039)\end{array}$ \\
\hline value & & & & $\begin{array}{c}0.223^{* * *} \\
(0.044)\end{array}$ \\
\hline dangerous & & $\begin{array}{c}-0.116^{* *} \\
(0.048)\end{array}$ & & \\
\hline \multirow[t]{2}{*}{ gender } & 0.048 & 0.285 & 0.183 & 0.238 \\
\hline & $(0.348)$ & $(0.319)$ & $(0.416)$ & $(0.309)$ \\
\hline \multirow[t]{2}{*}{ age } & 0.221 & 0.045 & 0.045 & 0.010 \\
\hline & $(0.173)$ & $(0.165)$ & $(0.201)$ & $(0.163)$ \\
\hline \multirow[t]{2}{*}{ edu } & 0.076 & -0.233 & 0.018 & -0.245 \\
\hline & $(0.195)$ & $(0.187)$ & $(0.237)$ & $(0.188)$ \\
\hline \multirow[t]{2}{*}{ Constant term } & $7.605^{* * *}$ & $19.946^{* * *}$ & $15.755^{* * *}$ & $15.554^{* * *}$ \\
\hline & $(1.295)$ & (1.261) & (1.408) & (1.427) \\
\hline $\mathrm{F}$ & 18.713 & 28.652 & 20.568 & 35.670 \\
\hline $\mathrm{R}^{2}$ & 0.176 & 0.302 & 0.168 & 0.340 \\
\hline $\mathrm{N}$ & 500 & 500 & 500 & 500 \\
\hline
\end{tabular}

Note: ${ }^{* *}$, and ${ }^{* *}$ are significant at the levels of $1 \%$, and $5 \%$, respectively. Robust standard error is in brackets

1. Research on the mechanism of green brand product functional crises

The mechanism test results for green brand product functional crises are shown in Table 5. Columns 1-2 represent the test results of the perceived risk effect and columns 3-4 represent the test results of the perceived value effect. The results in column 1 show that brand_crisis has a positive effect on dangerous at the $1 \%$ level; the value is 0.34 . The results in column 2 show that dangerous has a negative effect on brand_trust at the $1 \%$ level, with the value being -0.254 . According to the results, Hypothesis 3a can be accepted, with perceived risk playing an intermediary role in green brand product functional crisis and green brand trust. Both coefficient $\theta_{\text {med }}$ and coefficient $\varphi_{\text {med }}$ are significant, which indicates that the perceived risk effect exists. When the green brand has a product functional crisis, it will strengthen consumers' perceived risk, and this perceived risk will reduce consumers' trust in the green brand.

The results in column 3 of Table 5 show that brand_crisis has an impact on the perceived value at a $1 \%$ level of significance and that the correlation is negative; the value is -0.352 . Simultaneously, the results in column 4 show that perceived value has an impact on the brand_trust at a $1 \%$ level of significance and that the correlation is positive; the value is 0.242 . Both coefficient $\theta_{\text {med }}$ and coefficient $\varphi_{\text {med }}$ are significant, showing that the perceived value effect also exists. When the green brand has a product functional crisis, it will reduce consumers' perceived value of the green brand, thus reducing consumers' trust in the green brand. Based on the above conclusions, Hypothesis $2 \mathrm{a}$ can be accepted. Thus, it can be concluded that the perceived value plays an intermediary role between green brand product functional crises and green brand trust.

2. Research on the mechanism of green brand value-related crises

The mechanism test results for value-related brand crises are shown in Table 6. Columns 1-2 represent the test results for the perceived risk effect, and columns 3-4 represent the test results for the perceived value effect. The results in column 1 of Table 6 show that brand_crisis has an impact on dangerous at a $1 \%$ level of significance and that the correlation is positive; the value of the coefficient is 0.326 . The results in column 2 show that dangerous has an impact on brand_trust at a $1 \%$ level of significance and that the correlation is negative, with the value of the coefficient being -0.116 . According to the above conclusions, Hypothesis $3 b$ can be accepted. Thus, it can be concluded that perceived risk plays an intermediary role between green brand value-related crises and 
green brand trust. Both coefficient $\theta_{\text {med }}$ and coefficient $\varphi_{\text {med }}$ are significant, which indicates that the perceived risk effect does exist. When a green brand has a value-related crisis, it will strengthen consumers' perceived risk, which will reduce consumers' trust in the green brand.

The results in column 3 of Table 6 show that brand_crisis has an impact on value at a 1\% level of significance and that the correlation is negative; the value of the coefficient is -0.351 . Simultaneously, the results in column 4 show that the value has an impact on brand_trust at a $1 \%$ level of significance and that the correlation is positive; the value of the coefficient is 0.223 . According to the above conclusions, Hypothesis $2 b$ can be accepted, where the perceived value plays an intermediary role between green brand value-related crises and green brand trust. Both coefficient $\theta_{\text {med }}$ and coefficient $\varphi_{\text {med }}$ are significant, indicating that the perceived value effect also exists. When a green brand has a value-related crisis, it will reduce consumers' perceived value of the brand and reduce consumers' trust in the green brand.

In the second column of Table 5, when a green brand has a product functional crisis, the perceived risk of the brand has a significant negative impact on the green brand trust, and when the green brand has a value-related crisis, as shown in the second column of Table 6, the brand's perceived risk also has a significant negative impact on green brand trust. As such, Hypothesis 3 can be accepted. Thus, it can be concluded that a green brand crisis will increase consumers' perceived risk of a green brand and reduce green brand trust. Simultaneously, in column 4 of Table 5, when the green brand has a product functional crisis, the brand's perceived value has a significant positive impact on green brand trust, and in column 4 of Table 6, when the green brand has a value-related crisis, the brand's perceived value also has a significant positive impact on green brand trust. As such, Hypothesis 2 can be accepted. Thus, it can be concluded that a green brand crisis will reduce consumers' perceived value of the green brand and reduce consumers' green brand trust.

\subsubsection{Regulatory Effect Test}

When a consumer is more familiar with a green brand, the green brand trust will not be seriously affected after a green brand crisis occurs. Essentially, consumers' familiarity with the green brand will affect their cognition of the green brand crisis, thus differentiating consumers' impact on green brand trust. Therefore, referring to the practice in the existing literature, this paper constructs interactive items that involve brand familiarity and green brand crisis variables, brand_crisis_familiar, to test whether the regulatory effect of brand familiarity exists. The specific model's construction is as follows:

$$
\begin{aligned}
\text { Brand_trust }_{i, j}= & \alpha_{0}+\alpha_{1} \text { Brand_crisis }_{i, j}+\alpha_{2} \text { familiar }_{i, j}+\alpha_{3} \text { Brand_crisis }_{i, j} \times \text { familiar }_{i, j} \\
& +\sum \alpha_{k} \text { Control }_{i, j}+\varepsilon_{i, j}
\end{aligned}
$$

where familiar $_{i, j}$ is consumers' familiarity with the green brand. This paper measures brand familiarity through the three dimensions of often seeing the advertising of the brand's products or image, often seeing the display or sale of the brand's products, and often listening to others talk about or recommend the brand's products. Each answer is based on the levels of strongly disagree, disagree, generally agree, quite in agreement, and strongly agree, and are assigned to points 1-5, respectively. A higher score means that consumers are more familiar with the green brand, and these scores are finally summed up to obtain a comprehensive evaluation. Brand_crisis $s_{i, j} \times$ familiar $_{i, j}$ is the interactive term of green brand crisis and brand familiarity, and $\alpha_{3}$ is the coefficient concerned in this paper. If $\alpha_{3}$ is positive and significant, it means that brand familiarity reduces the impact on green brand trust when a green brand crisis occurs. The test results of an adjustment effect are shown in Table 7. 
Column 1 of Table 7 shows whether brand familiarity has a moderating effect on green brand crises and green brand trust in the event of a product functional crisis. The results show that, based on the controlling of individual characteristics, the coefficient of the interaction item Brand_crisis $i_{i, j} \times$ familiar $_{i, j}$ is statistically significant at the $10 \%$ level and the value of the coefficient is 0.016 , which shows that the more familiar consumers are with using the green brand, the lower their trust in the brand will be when a product functional crisis of the brand occurs. This proves Hypothesis H4a: Brand familiarity plays a regulatory role in product functional crises and green brands. Essentially, this situation exists in both product functional crises and value-related crises. The results in column 2 of Table 7 show that the coefficient of the interaction item Brand_crisis $i_{i, j} \times$ familiar $_{i, j}$ is statistically significant at the $10 \%$ level and the value of the coefficient is 0.019 , which indicates that, in the face of a green brand value-related crisis, brand familiarity will also reduce consumers' green brand trust, that is, Hypothesis $\mathrm{H} 4 \mathrm{~b}$ - brand familiarity plays a regulatory role between value-related crises and green brand trust-has been verified.

Table 7. Moderating effect of brand familiarity.

\begin{tabular}{ccc}
\hline & $\begin{array}{c}(\mathbf{1}) \\
\text { Product Functional Crisis } \\
\text { brand_trust }\end{array}$ & $\begin{array}{c}(\mathbf{2}) \\
\text { Value-Related Crisis } \\
\text { brand_trust }\end{array}$ \\
\hline brand_crisis & $-0.567^{* * *}$ & $-0.517^{* * *}$ \\
familiar & $(0.070)$ & $(0.105)$ \\
& -0.224 & -0.138 \\
brand_crisis_familiar & $(0.203)$ & $(0.240)$ \\
gender & $0.016^{*}$ & $0.019 *$ \\
& $(0.008)$ & $(0.010)$ \\
age & 0.419 & 0.336 \\
& $(0.336)$ & $(0.316)$ \\
edu & 0.101 & 0.075 \\
& $(0.165)$ & $(0.163)$ \\
Constant term & -0.138 & -0.139 \\
& $(0.180)$ & $(0.182)$ \\
$\mathrm{F}$ & $20.289 * * *$ & $18.490 * * *$ \\
$\mathrm{R}^{2}$ & $(1.989)$ & $(2.838)$ \\
$\mathrm{N}$ & 43.175 & 35.247 \\
& 0.364 & 0.339 \\
& 500 & 500 \\
\hline Note: $* * *$ and ${ }^{*}$ are significant at the levels of $1 \%$ and $10 \%$, respectively. Robust standard error is in brackets.
\end{tabular}

\subsection{Heterogeneity Analysis}

Although the above results have confirmed that a green brand crisis will negatively impact green brand trust and that different green brand crises have different effects on consumers' green brand trust, the above test results cannot test the impacts of brands of different enterprises on green brand trust. To test the heterogeneity of the impacts of different types of green brand crises of different enterprises, in the questionnaire design, two brand crisis materials were designed for each brand. One was mainly about crises of product function, and the other was mainly about crises of the enterprise value. About 100 questionnaires were distributed for each. The test results for the different types of brand crises are shown in Tables 8 and 9. 
Table 8. Heterogeneity analysis of product functional crises in five brands.

\begin{tabular}{|c|c|c|c|c|c|}
\hline & $\begin{array}{c}\text { (1) } \\
\text { Huawei } \\
\text { brand_trust }\end{array}$ & $\begin{array}{c}\text { (2) } \\
\text { Lenovo } \\
\text { brand_trust }\end{array}$ & $\begin{array}{c}\text { (3) } \\
\text { Midea } \\
\text { brand_trust }\end{array}$ & $\begin{array}{c}\text { (4) } \\
\text { TCL } \\
\text { brand_trust }\end{array}$ & $\begin{array}{c}\text { (5) } \\
\text { Gree } \\
\text { brand_trust }\end{array}$ \\
\hline brand_crisis & $\begin{array}{c}-0.325^{* * *} \\
(0.085)\end{array}$ & $\begin{array}{c}-0.540^{* * *} \\
(0.046)\end{array}$ & $\begin{array}{c}-0.554^{* * * *} \\
(0.049)\end{array}$ & $\begin{array}{c}-0.440^{* * *} \\
(0.085)\end{array}$ & $\begin{array}{c}-0.381^{* * *} \\
(0.065)\end{array}$ \\
\hline gender & $\begin{array}{c}0.028 \\
(0.859)\end{array}$ & $\begin{array}{l}-0.147 \\
(0.670)\end{array}$ & $\begin{array}{c}0.483 \\
(0.774)\end{array}$ & $\begin{array}{c}0.664 \\
(0.664)\end{array}$ & $\begin{array}{c}0.277 \\
(1.063)\end{array}$ \\
\hline age & $\begin{array}{c}0.293 \\
(0.540)\end{array}$ & $\begin{array}{c}0.227 \\
(0.238)\end{array}$ & $\begin{array}{l}-0.421 \\
(0.378)\end{array}$ & $\begin{array}{c}0.178 \\
(0.390)\end{array}$ & $\begin{array}{c}0.402 \\
(0.435)\end{array}$ \\
\hline edu & $\begin{array}{l}-0.492 \\
(0.808)\end{array}$ & $\begin{array}{c}0.365 \\
(0.276)\end{array}$ & $\begin{array}{l}-0.447 \\
(0.349)\end{array}$ & $\begin{array}{l}-0.048 \\
(0.401)\end{array}$ & $\begin{array}{l}-0.622 \\
(0.728)\end{array}$ \\
\hline Constant term & $\begin{array}{c}16.702^{* * *} \\
(2.941)\end{array}$ & $\begin{array}{c}19.891^{* * *} \\
(2.054)\end{array}$ & $\begin{array}{c}23.348^{* * *} \\
(2.556)\end{array}$ & $\begin{array}{c}17.850^{* * *} \\
(2.538)\end{array}$ & $\begin{array}{c}17.853^{* * *} \\
(3.891)\end{array}$ \\
\hline $\mathrm{F}$ & 4.947 & 41.156 & 39.509 & 7.426 & 9.730 \\
\hline $\mathrm{R}^{2}$ & 0.180 & 0.591 & 0.585 & 0.288 & 0.273 \\
\hline $\mathrm{N}$ & 100 & 100 & 100 & 100 & 100 \\
\hline
\end{tabular}

Note: ${ }^{* *}$ is significant at the levels of $1 \%$. Robust standard error is in brackets.

Table 9. Heterogeneity analysis of value-related crises in five brands.

\begin{tabular}{|c|c|c|c|c|c|}
\hline & $\begin{array}{c}\text { (1) } \\
\text { Huawei } \\
\text { brand_trust }\end{array}$ & $\begin{array}{c}\text { (2) } \\
\text { Lenovo } \\
\text { brand_trust }\end{array}$ & $\begin{array}{c}\text { (3) } \\
\text { Midea } \\
\text { brand_trust }\end{array}$ & $\begin{array}{c}\text { (4) } \\
\text { TCL } \\
\text { brand_trust }\end{array}$ & $\begin{array}{c}\text { (5) } \\
\text { Gree } \\
\text { brand_trust }\end{array}$ \\
\hline brand_crisis & $\begin{array}{c}-0.379 * * * \\
(0.106)\end{array}$ & $\begin{array}{c}-0.407^{* * *} \\
(0.077)\end{array}$ & $\begin{array}{c}-0.456^{* * * *} \\
(0.083)\end{array}$ & $\begin{array}{c}-0.391^{* * *} \\
(0.085)\end{array}$ & $\begin{array}{c}-0.395^{* * *} \\
(0.075)\end{array}$ \\
\hline gender & $\begin{array}{l}1.975^{* *} \\
(0.833)\end{array}$ & $\begin{array}{l}-0.158 \\
(0.563)\end{array}$ & $\begin{array}{l}-0.189 \\
(0.654)\end{array}$ & $\begin{array}{c}0.282 \\
(0.717)\end{array}$ & $\begin{array}{l}-0.088 \\
(0.858)\end{array}$ \\
\hline age & $\begin{array}{l}-0.498 \\
(0.410)\end{array}$ & $\begin{array}{c}0.031 \\
(0.331)\end{array}$ & $\begin{array}{c}0.270 \\
(0.293)\end{array}$ & $\begin{array}{c}0.552 \\
(0.412)\end{array}$ & $\begin{array}{l}-0.075 \\
(0.464)\end{array}$ \\
\hline edu & $\begin{array}{c}0.020 \\
(0.561)\end{array}$ & $\begin{array}{l}-0.014 \\
(0.311)\end{array}$ & $\begin{array}{c}-0.073 \\
(0.418)\end{array}$ & $\begin{array}{c}0.236 \\
(0.361)\end{array}$ & $\begin{array}{l}-0.186 \\
(0.894)\end{array}$ \\
\hline Constant term & $\begin{array}{c}16.797^{* * * *} \\
(2.607)\end{array}$ & $\begin{array}{c}18.038^{* * *} \\
(2.473)\end{array}$ & $\begin{array}{c}19.923^{* * *} \\
(2.424)\end{array}$ & $\begin{array}{c}15.436^{* * *} \\
(3.685)\end{array}$ & $\begin{array}{c}19.268^{* * *} \\
(3.014)\end{array}$ \\
\hline $\mathrm{F}$ & 7.257 & 7.120 & 9.122 & 7.660 & 7.287 \\
\hline $\mathrm{R}^{2}$ & 0.226 & 0.427 & 0.438 & 0.284 & 0.232 \\
\hline $\mathrm{N}$ & 100 & 100 & 100 & 100 & 100 \\
\hline
\end{tabular}

\subsubsection{Heterogeneity Analysis of Product Functional Brand Crises}

Table 8 shows the impact of product functional crises on consumers' green brand trust. The result in column 1 shows that brand_crisis negatively affects the brand_trust of Huawei, and the value of the coefficient is -0.325 at the $1 \%$ level, indicating that consumers trust in Huawei's brand will be reduced in the event of a product functional crisis. The results in column 2 show the impact of a brand crisis on green brand trust when Lenovo has a product functional crisis. The results show that brand_crisis negatively affects the brand_trust of Lenovo, and the value of the coefficient is -0.540 at the $1 \%$ level. The third column shows the impact of consumers' trust in Midea in the event of a brand crisis. The results show that brand_crisis also negatively affects the brand_trust of Midea at the $1 \%$ level, and the value of the coefficient is -0.554 . Column 4 shows that brand_crisis negatively affects the brand_trust of TCL at the $1 \%$ level, and the value of the coefficient is -0.440 . The results in column 5 show that the impact coefficient of a product functional brand crisis negatively affects the consumer green brand trust in the Gree air conditioner at the $1 \%$ level, and the value of the coefficient is -0.381 .

To summarize, although consumers' trust in green brands will decline in the event of a product functional brand crisis, the degrees of impact are different for all brands. Our results show that the impacts of a product functional crisis on green brand trust, from small 
to large, are for Huawei, Gree, TCL, Lenovo, and Midea. This may be due to consumers' differences in familiarity with the different brands and the fact that the brand image of the light of domestic goods is shaped by Huawei and Gree. The image and advertising coverage of a brand increase the consumers' crisis tolerance for the brand. As such, this difference in impact finally occurs.

\subsubsection{Heterogeneity Analysis of Value-Related Brand Crises}

Table 9 shows the impacts of consumer value-related crises on green brand trust. The result in column 1 shows that brand_crisis negatively affects the brand_trust of Huawei at the level of $1 \%$, and the value of the coefficient is -0.379 , which indicates that when Huawei has a value-related crisis, consumers' trust in its brand is reduced. The results in column 2 are the impact of brand_crisis on brand trust when Lenovo has a value-related crisis. The results show that brand_crisis negatively affects the brand_trust of Lenovo at the level of $1 \%$, and the value of the coefficient is -0.407 . The third column shows the impact on consumers' trust in the event of a value-related brand crisis for Midea. The results show that brand_crisis also negatively affects the brand_trust of Midea at the $1 \%$ level, with the value of the coefficient being -0.456 . Column 4 shows that brand_crisis negatively affects the brand_trust of TCL at the level of $1 \%$, with the value of the coefficient being -0.391 . The results in column 5 show that the impact coefficient of a value-related brand crisis negatively affects the consumer brand trust in Gree at the $1 \%$ level, and the value of the coefficient is -0.395 .

This is consistent with the conclusion about product function crises. For different enterprises, the impacts of value-related brand crises on the green brand trust of different enterprises are different. Moreover, it is worth noting that when value-related crises occur for Huawei mobile phones and Gree air conditioners, the impacts of the green brand crises on green brand trust are greater than with product functional crisis, which is different from the above research. This may be because consumers have the expectation of the rise of domestic products on the two brands. A large part of the expected value for consumers for the brand may lie in its added value rather than the value of the product itself. Therefore, when an enterprise has value-related problems, it will have a greater impact on the trust of consumers.

The above results show that different types of green brand crises have different effects on green brand trust. Moreover, different types of green brand crises affect consumers' perceived value and perceived risk. The results of the mechanism test show that different types of green brand crises may have different effects on perceived value and perceived risk, thus differentiating consumers' trust in the brands. The five brands selected in this paper were Huawei, Lenovo, Gree, TCL, and Midea; these were selected based on the top five enterprises with the highest frequency of crisis events in the last 10 years in the list of Chinese green brands that was published earlier. According to the empirical results, the impact of green brand product functional crises on consumers' green brand trust is more significant than that of value-related crises. This may be because green brand product functional crises will lead consumers to fail to meet their needs when purchasing such products, and green brand value-related crises will not directly affect the added green value and efficacy of green products. Therefore, consumers may not pay significant attention to this type of crisis. However, if consumers have more emotional dependence on the products of a green brand, a value-related crisis may be more severe than a product functional crisis.

\section{Conclusions}

Consumers' consumption of green brands is based on functionality, and more attention is paid to the value satisfaction that they can bring. This paper studies the unique characteristics of green brands, and it can provide new research ideas for studying the relationship between brand crises and brand trust and provide a theoretical basis for revealing the internal mechanism between green brand crises and green brand trust. The results show that green perceived value and green perceived risk play an intermediary role between 
green brand crises and consumer green brand trust, and consumers' familiarity with a green brand can affect this relationship. This shows that in the face of crisis events, green brands can deal with them by improving consumers' perceived value and perceived risk of green products, and improving consumers' familiarity with the brand can also reduce the serious consequences of a green brand crisis. For example, this can be done by improving consumers' perceived value of a green brand through green brand certification, green brand rationality, and corporate public welfare behaviour, reducing consumers' perceived risk for green brands by establishing a good green brand image and green brand authenticity, and improving consumers' brand familiarity through green advertising. Although this paper selected the five green brands with the highest frequency of crisis events in China, these brands belong to the manufacturing industry and are not widely representative. In the future, we can also study the categories in which consumers pay more direct attention to their green attributes, such as food and dairy products.

Moreover, the sample in this paper was from data collected by 1000 networks, which still cannot reflect the most realistic situation for the enormous population of China and the reality that there continues to be some kind of gap between the rich and the poor. Whether there are still similar findings for a broader region or different categories must further verified. In addition, different consumer characteristics, the relevance of green brand crises to principal businesses, and the differences in abilities to handle brand crises may affect the relationship between green brand crises and green brand trust, which must also be explored in the future.

Author Contributions: Conceptualization, X.S. and G.L.; methodology, G.L.; software, G.L.; validation, G.L.; formal analysis, G.L.; investigation, X.S. and G.L.; resources, X.S.; data curation, G.L.; writing-original draft preparation, G.L.; writing-review and editing, X.S.; visualization, X.S.; supervision, X.S.; project administration, G.L.; funding acquisition, X.S. All authors have read and agreed to the published version of the manuscript.

Funding: This study was supported by the National Natural Science Foundation of China (NSFC) (NO.71772143).

Institutional Review Board Statement: Not applicable.

Informed Consent Statement: Informed consent was obtained from all subjects involved in the study.

Data Availability Statement: Not applicable.

Conflicts of Interest: The authors declare no conflict of interest. The funders had no role in the design of the study; in the collection, analyses, or interpretation of data; in the writing of the manuscript, or in the decision to publish the results.

\section{References}

1. Delmas, M.A.; Burbano, V.C. The drivers of greenwashing. Calif. Manag. Rev. 2011, 54, 64-87. [CrossRef]

2. Zhang, Q.; Sun, X. Theoretical construction and measurement of green brand value from the perspective of consumers. J. Beijing Univ. Technol. Technol. Soc. Sci. Ed. 2015, 30, 85-92.

3. Lewicki, R.J.; Brinsfield, C. Trust repair. Annu. Rev. Organ. Psychol. Organ. Behav. 2017, 4, 287-313. [CrossRef]

4. Kim, P.; Dirks, K.T.; Cooper, C.D. The repair of trust: A dynamic bilateral perspective and multilevel conceptualization. Acad. Manag. Rev. 2009, 34, 401-422. [CrossRef]

5. Kim, P.H.; Cooper, C.D.; Dirks, K.T.; Ferrin, D.L. Repairing trust with individuals vs. groups. Organ. Behav. Hum. Decis. Process. 2013, 120, 1-14. [CrossRef]

6. Bozic, B.; Siebert, S.; Martin, G. A strategic action fields perspective on organizational trust repair. Eur. Manag. J. 2019, 37, 58-66. [CrossRef]

7. Pace, K.M.; Fediuk, T.A.; Botero, I.C. The acceptance of responsibility and expressions of regret in organizational apologies after a transgression. Corp. Commun. Int. J. 2010, 15, 410-427. [CrossRef]

8. Xia, X.; Teng, F.; Gu, X. Reputation repair and corporate donations: An investigation of responses to regulatory penalties. China J. Account. Res. 2019, 12, 293-313. [CrossRef]

9. Brown, J.A.; Buchholtz, A.K.; Dunn, P. Moral salience and the role of goodwill in firm-stakeholder trust repair. Bus. Ethic- Q. 2016, 26, 181-199. [CrossRef] 
10. Fuoli, M.; van de Weijer, J.; Paradis, C. Denial outperforms apology in repairing organizational trust despite strong evidence of guilt. Public Relat. Rev. 2017, 43, 645-660. [CrossRef]

11. Schweitzer, M.E.; Hershey, J.C.; Bradlow, E.T. Promises and lies: Restoring violated trust. Organ. Behav. Hum. Decis. Process. 2006, 101, 1-19. [CrossRef]

12. Tomlinson, E.C.; Mryer, R.C. The role of causal attribution dimensions in trust repair. Acad. Manag. Rev. 2009, 34, 85-104. [CrossRef]

13. Guo, R.; Zhang, W.; Wang, T.; Li, C.B.; Tao, L. Timely or considered? Brand trust repair strategies and mechanism after greenwashing in China-From a legitimacy perspective. Ind. Mark. Manag. 2018, 72, 127-137. [CrossRef]

14. Poppo, L.; Schepker, D. Repairing public trust in organizations. Corp. Reput. Rev. 2010, 13, 124-141. [CrossRef]

15. Lin, C.; Xu, X. Exploring bottled water purchase intention via trust in advertising, product knowledge, consumer beliefs and theory of reasoned action. Soc. Sci. 2021, 10, 295. [CrossRef]

16. Zameer, H.; Wang, Y.; Yasmeen, H.; Mubarak, S. Green innovation as a mediator in the impact of business analytics and environmental orientation on green competitive advantage. Manag. Decis. 2020. [CrossRef]

17. Novemsky, N.; Dhar, R.; Schwarz, N.; Simonson, I. Preference fluency in choice. J. Mark. Res. 2007, 44, 347-356. [CrossRef]

18. Dutta, S.; Pullig, C. Effectiveness of corporate responses to brand crises: The role of crisis type and response strategies. J. Bus. Res. 2011, 64, 1281-1287. [CrossRef]

19. Han, B.; Wang, L.; Yu, M. Research on the impact of social stratum and brand crisis types on brand evaluation and purchase intention. Manag. Rev. 2018, 30, 10.

20. Lee, A.; Levy, Y. The effect of information quality on trust in e-government systems' transformation. Transform. Gov. People Process. Policy 2014, 8, 76-100. [CrossRef]

21. Wei, H.; Li, Q.; Yang, D. Dynamic evolution mechanism of social relationship conflict in brand crisis-A study based on hermeneutics. China Ind. Econ. 2015, 16. [CrossRef]

22. Gillespie, N.; Dietz, G. Trust repair after an organization-level failure. Acad. Manag. Rev. 2009, 34, 127-145. [CrossRef]

23. Zeithaml, V.A. Consumer perceptions of price, quality, and value: A means-end model and synthesis of evidence. J. Mark. 1988, 52, 2-22. [CrossRef]

24. Jin, L. The impact of online word-of-mouth information on consumers' purchase decision: An experimental study. Econ. Manag. 2007, 29, 36-42.

25. da Luz, V.V.; Mantovani, D.; Nepomuceno, M.V. Matching green messages with brand positioning to improve brand evaluation. J. Bus. Res. 2020, 119, 25-40. [CrossRef]

26. Sultan, F.; Urban, G.; Shankar, V.; Bart, I. Determinants and Role of Trust in e-Business: A Large Scale Empirical Study. 2003. Available online: https:/ / dspace.mit.edu/handle/1721.1/1826 (accessed on 30 November 2021).

27. Zhang, N.; Zhou, Z.; Zhan, G.; Zhou, N. How does online brand community climate influence community identification? The mediation of social capital. J. Theor. Appl. Electron. Commer. Res. 2021, 16, 922-936. [CrossRef]

28. Yu, W.; Han, X.; Ding, L.; He, M. Organic food corporate image and customer co-developing behavior: The mediating role of consumer trust and purchase intention. J. Retail. Consum. Serv. 2021, 59, 102377. [CrossRef]

29. Roberts, J.A. Green consumers in the 1990s: Profile and implications for advertising. J. Bus. Res. 1996, 36, 217-231. [CrossRef]

30. Esmaeilzadeh, S.; Ashrafi-Rizi, H.; Shahrzadi, L.; Mostafavi, F. A survey on adolescent health information seeking behavior related to high-risk behaviors in a selected educational district in Isfahan. PLoS ONE 2018, 13, e0206647. [CrossRef]

31. Brown, J.J.; Reingen, P.H. Social ties and word-of-mouth referral behavior. J. Consum. Res. 1987, 14, 350-362. [CrossRef]

32. Wang, X.; Chen, S.; Wu, J. Analysis on Influencing Factors of consumers' purchase behavior under online pre-sale-An Empirical Study Based on Taobao's spring and summer women's clothing in 2018. Nankai Manag. Rev. 2020, 23, 6-17, 42.

33. Chen, Y.-S.; Chang, C.-H. Greenwash and green trust: The mediation effects of green consumer confusion and green perceived risk. J. Bus. Ethics 2013, 114, 489-500. [CrossRef]

34. Chen, Y.; Chang, C. Enhance green purchase intentions: The roles of green perceived value, green perceived risk, and green trust. Manag. Decis. 2012, 50, 502-520. [CrossRef]

35. Ritter, Á.M.; Borchardt, M.; Vaccaro, G.L.R.; Pereira, G.M.; Almeida, F. Motivations for promoting the consumption of green products in an emerging country: Exploring attitudes of Brazilian consumers. J. Clean. Prod. 2015, 106, 507-520. [CrossRef]

36. Keller, K.L. Conceptualizing, measuring, and managing customer-based brand equity. J. Mark. 1993, 57, 1-22. [CrossRef]

37. Lu, Q.; Fu, H. The impact of brand social power on Purchase Intention-An Empirical Study Based on the theory of "evaluation emotion response". China Circ. Econ. 2016, 30, 10.

38. Shapiro, S.A.; Nielsen, J.H. What the blind eye sees: Incidental change detection as a source of perceptual fluency. J. Consum. Res. 2013, 39, 1202-1218. [CrossRef]

39. Toyokawa, S.; Takagi, T. The collapse of the 'myth of longevity'and the construction of alternatives. The case of the Okinawan health food industry. J. Organ. Discourse 2020, 1, 22-29. [CrossRef]

40. Sinha, J.; Lu, F.-C. "I" value justice, but "we" value relationships: Self-construal effects on post-transgression consumer forgiveness. J. Consum. Psychol. 2016, 26, 265-274. [CrossRef]

41. Shan, C.; Yu, M.; Wang, L. Research on Influencing Factors of brand extension on consumer brand loyalty-Based on brand concept and brand extension Architecture. Mod. Manag. Sci. 2015, 3. [CrossRef] 
42. Park, S.-Y.; Lee, S.W. Effects of a perceived brand crisis on product evaluation and purchase intention: The moderating roles of brand credibility and brand attachment. J. Glob. Sch. Mark. Sci. 2013, 23, 213-226. [CrossRef]

43. Cronin, J.J., Jr.; Brady, M.K.; Hult, G.T.M. Assessing the effects of quality, value, and customer satisfaction on consumer behavioral intentions in service environments. J. Retail. 2000, 76, 193-218. [CrossRef]

44. Cox, D.F.; Rich, S.U. Perceived risk and consumer decision-making-The case of telephone shopping. J. Mark. Res. 1964, 1, 32-39. [CrossRef]

45. Kent, R.J.; Allen, C.T. Competitive interference effects in consumer memory for advertising: The role of brand familiarity. J. Mark. 1994, 58, 97-105. [CrossRef]

46. Lewbel, A. Constructing instruments for regressions with measurement error when no additional data are available, with an application to patents and R\&D. Econom. J. Econom. Soc. 1997, 65, 1201. [CrossRef] 